\title{
Kemampuan Bacillus subtilis dan Lysinibacillus sp. dalam Silika Nano dan Serat Karbon untuk Menginduksi Ketahanan Bawang Merah terhadap Penyakit Bercak Ungu (Alternaria porri (Ell.) Cif)
}

\author{
Hersanti $^{1}$, Sudarjat ${ }^{1}$ dan Andina Damayanti ${ }^{2}$ \\ ${ }^{1}$ Departemen Hama dan Penyakit Tumbuhan, Fakultas Pertanian, Universitas Padjadjaran \\ ${ }^{2}$ Program Studi Agroteknologi, Fakultas Pertanian, Universitas Padjadjaran \\ *Alamat korespondensi: hersanti09@gmail.com
}

\begin{abstract}
The ability of Bacillus subtilis and Lysinibacillus sp. singly or mixed, with carbon fiber and nano silica to induce resistance of shallot to purple blotch
\end{abstract}

Purple blotch disease caused by Alternaria porri is one of the major disease on shallot. One of the methods that can be applied to control the disease is the use of antagonistic bacteria. Antagonistic bacteria can be used as a resistance inducer to suppress pathogen development. In this study, Bacillus subtilis and Lysinibacillus sp. were formulated in carbon fiber as a carrier and nano silica $3 \%$ as a complementary. This study was conducted to determine the ability of Bacillus subtilis and Lysinibacillus sp. singly or mixed, with carbon fiber and nano silica to induce resistance of shallot to purple blotch. The experiment was conducted at the Laboratory of Phytopathology, Departement of Plant Pest and Diseases and Ciparanje Green House, Faculty of Agriculture, Universitas Padjadjaran from December 2017 until July 2018. Suspension of Bacillus subtilis and Lysinibacillus sp. singly or mixed were formulated in carbon fiber 80 Mesh and 3\% nano silica. The experiment used Randomized Block Design consisted of 8 treatments with 3 replications. Each replication consisted of 5 plants. The results showed that the mixture of Bacillus subtilis and Lysinibacillus sp. in 3\% silica nano and carbon fiber was the ablest treatment to increase the resistance of shallot to purple blotch by $71,2 \%$.

Keywords: Antagonistic bacteria, Biocontrol

\begin{abstract}
ABSTRAK
Penyakit bercak ungu yang disebabkan oleh Alternaria porri merupakan salah satu penyakit utama pada bawang merah. Salah satu metode yang dapat digunakan untuk pengendalian yaitu menggunakan bakteri antagonis. Bakteri antagonis dapat digunakan sebagai penginduksi ketahanan tanaman untuk menekan perkembangan penyakit. Pada penelitian ini, Bacillus subtilis dan Lysinibacillus sp. diformulasikan dalam serat karbon sebagai bahan pembawa dan silika nano 3\% sebagai bahan pelengkap. Percobaan ini dilakukan untuk mengetahui kemampuan bakteri Bacillus subtilis dan Lysinibacillus sp. secara tunggal maupun campuran dalam serat karbon dan silika nano $3 \%$ untuk menginduksi ketahanan bawang merah terhadap penyakit bercak ungu. Percobaan ini dilaksanakan di Laboratorium Fitopatologi, Departemen Hama dan Penyakit Tumbuhan dan Rumah Kaca, Ciparanje, Fakultas Pertanian, Universitas Padjadjaran mulai dari bulan Desember 2017 hingga Juli 2018. Suspensi Bacillus subtilis dan Lysinibacillus sp. secara tunggal maupun campuran diformulasikan pada serat karbon dan silika nano 3\%. Percobaan menggunakan rancangan acak kelompok yang terdiri dari 8 perlakuan dengan 3 ulangan. Setiap ulangan terdiri dari 5 tanaman. Dari hasil percobaan diketahui bahwa campuran B. subtilis dan Lysinibacillus sp. dalam silika nano 3\% serta serat karbon mampu meningkatkan ketahanan bawang merah terhadap penyakit bercak ungu dengan persentase hambatan sebesar $71,2 \%$.
\end{abstract}

Kata Kunci: Bakteri antagonis, Biokontrol 


\section{PENDAHULUAN}

Bawang merah merupakan salah satu komoditas hortikultura yang banyak diminati oleh masyarakat di Indonesia dan memiliki prospek bisnis yang tinggi. Penyakit bercak ungu merupakan salah satu penyakit utama pada tanaman bawang merah yang disebabkan oleh jamur Alternaria porri (Ell.) Cif. (Tarigan dkk., 2015). Kehilangan hasil dari bawang merah akibat penyakit ini yaitu sebesar 3 sampai 57\% (Suhardi dkk., 1994). Selain menyerang bawang merah amur $A$. porri, dapat menyerang bawang putih, bawang bombay, dan bawang daun (Hadisutrisno dkk., 1996).

Petani biasanya mengendalikan A. porri dengan menggunakan fungisida sintetik. Akan tetapi, penggunaan fungisida sintetik secara terus menerus dapat menimbulkan berbagai dampak negatif bagi lingkungan, mikoorganisme non sasaran bahkan dapat mengganggu kesehatan manusia (Sari dkk., 2016). Melihat kondisi ini, perlu dibuat suatu pengendalian yang ramah lingkungan dan juga mampu untuk mengendalikan $A$. porri. Salah satunya, dengan cara menginduksi resistensi menggunakan mikroba antagonis.

Induksi resistensi merupakan salah satu proses menstimulasi ketahanan tanaman tanpa adanya introduksi gen-gen baru. Induksi resistensi menyebabkan kondisi fisiologis yang mengatur sistem ketahanan menjadi aktif dan atau menstimulasi mekanisme resistensi alami pada tanaman inang (Zhang et al., 2007). Beberapa mikroba antagonis dapat mengendalikan patogen dengan mekanisme induksi resistensi, seperti Bacillus subtilis dan Lysinibacillus sp. (Pieterse et al., 2014; Leiwakabessy et al., 2018).

Bakteri B. subtilis PGPR merupakan salah satu bakteri antagonis yang mampu menginduksi ketahanan sistemik pada tanaman atau Systemic induced resistance (Pieterse et al., 2014). Menurut Leiwakabessy (2018), Lysinibacullus sp. merupakan bakteri endofit yang mampu melakukan induksi resistensi secara sistemik terhadap Xanthomonas oryzae, penyebab penyakit hawar daun bakteri pada padi. Kemampuan mikroba antagonis dalam menekan perkembangan patogen dapat ditingkatkan dengan cara melakukan konsorsium atau penggabungan.

Penggunaan konsorsium mikroba antagonis, memiliki kelebihan yaitu mampu meningkatkan pertumbuhan tanaman, menekan perkembangan patogen, meningkatkan ketahanan tanaman, dan mampu meningkatkan hasil tanaman (Aiman dkk.,
2017). Menurut Berendsen (2018), penggunaan konsorsium mikroba antagonis efektif untuk menekan perkembangan penyakit dibandingkan dengan penggunaan tunggal, karena dengan penggunaan konsorsium mikroba antagonis dapat bersinergis.

Penggunaan mikroba antagonis dalam mengendalikan patogen suatu tanaman memerlukan bahan pembawa untuk dapat memperpanjang masa simpan serta mudah untuk diaplikasikan ke tanaman (Hanudin dkk., 2011). Contohnya adalah serat karbon 80 Mesh yang memiliki permukaan yang luas sebagai tempat untuk melekatnya agen pengendali hayati dalam suatu formulasi biopestisida, sehingga serat karbon dapat digunakan sebagai bagan pembawa dari mikroba antagonis (Ruhyaman dkk., 2017).

Suatu formulasi, selain memiliki bahan aktif dan bahan pembawa, perlu ditambahkan dengan bahan pelengkap agar formulasi tersebut dapat bekerja secara optimal. Bahan pelengkap yang dapat digunakan contohnya silika nano. Silika diterapkan dalam ukuran nano agar tanaman mudah menyerap silika dengan optimal (Yuliani dkk., 2015). Penggunaan serat karbon 80 Mesh dan silika nano sebelumnya telah dikembangkan oleh Ruhyaman (2017) dan Hersanti (2017), bakteri B. subtilis dan Lysinibacillus sp. dalam formulasi silika nano dan serat karbon 80 Mesh dengan konsentrasi 5\% merupakan formulasi dan konsentrasi terbaik untuk viabilitas bakteri $B$. subtilis dan Lysinibacillus sp. serta mampu menekan pekermbangan penyakit Ralstonia solacrarum secara invitro. Berdasarkan potensi tersebut maka diharapkan kemampuan dari B. subtilis, Lysinibacillus sp., serat karbon dan silika nano dalam bentuk biopestisida dapat digunakan untuk meningkatkan ketahanan bawang merah terhadap penyakit $A$. porri yang berwawasan lingkungan dan berkelanjutan.

\section{BAHAN DAN METODE}

Percobaan dilaksanakan di Laboratorium Fitopatologi, Departemen Hama dan Penyakit Tumbuhan dan di Rumah Kaca, Ciparanje, Fakultas Pertanian, Universitas Padjadjaran mulai dari bulan Desember 2017 hingga Juli 2018. Percobaan menggunakan Rancangan Acak Kelompok (RAK) yang terdiri dari 8 perlakuan dengan 3 ulangan. Setiap ulangan terdiri dari 5 tanaman. Perlakuan yang diuji dapat dilihat pada Tabel 1.

Tabel 1. Perlakuan yang diuji 


\begin{tabular}{ll}
\hline Kode & \multicolumn{1}{c}{ Perlakuan } \\
\hline A & $\begin{array}{l}\text { B. subtilis + Lysinibacillus } \text { sp. + serat } \\
\text { karbon 80 mesh + silika nano 3\% }\end{array}$ \\
B & $\begin{array}{l}\text { B. subtilis + serat karbon 80 mesh + silika } \\
\text { nano 3\% }\end{array}$ \\
C & $\begin{array}{l}\text { Lysinibacillus } \text { sp. + serat karbon 80 mesh + } \\
\text { silika nano 3\% }\end{array}$ \\
D & Serat karbon 80 mesh + silika nano 3\% \\
E & B. subtilis \\
F & Lysinibacillus sp. \\
G & B. subtilis + Lysinibacillus sp. \\
H & Kontrol \\
\hline
\end{tabular}

\section{Persiapan Isolat Patogen Alternaria porri}

Patogen $A$. porri yang diuji adalah koleksi dari Balai Penelitian Sayuran (BALITSA), diperbanyak kembali pada media Half-strength Shallot Dextrose Agar (SDA). Media Half-strength SDA merupakan media dengan menggunakan $50 \mathrm{~g}$ bawang merah, $10 \mathrm{~g}$ agar, $10 \mathrm{~g}$ dextrose, dan $500 \mathrm{ml}$ aquadest. Kemudian, diambil bulatan kecil dari $A$. porri dengan menggunakan cork borer. Kemudian, bulatan tersebut diletakkan di tengah media. Pemanenan $A$. porri dilakukan pada saat $A$. porri berumur 2 minggu hingga 3 minggu. Hal pertama yang dilakukan yaitu menuangkan aquadest sebanyak $10 \mathrm{ml}$ di dalam cawan Petri. Lalu, digosok secara perlahan dengan mengunakan ose, sehingga jamur $A$. porri terangkat, dan disimpan dalam wadah semprot.

\section{Pembuatan Formulasi Uji}

Menyiapkan bakteri B. subtillis dan Lysinibacillus $\mathrm{CK}_{3}$ yang telah diperbanyak pada media Nutrient Agar (NA). Kemudian, diinkubasi selama 48 jam pada suhu ruangan. Setelah itu, semua proses dilakukan di dalam Laminar Air Flow (LAF). Pembuatan suspensi bakteri B. subtilis dan Lysinibacillus $\mathrm{CK} \quad \mathrm{U}_{3}$ dilakukan dengan cara menambahkan aquadest steril sebanyak $5 \mathrm{ml}$ pada cawan Petri media agar yang telah ditumbuhi biakan bakteri. Selanjutnya, bakteri dipanen dengan menggunakan batang L secara perlahan, sehingga membentuk suspensi dengan aquadest. Suspensi bakteri lalu dimasukkan ke dalam media nutrient broth (NB), dan diinkubasikan dengan shaker selama 13 jam. Kerapatan yang diambil yaitu lebih dari $10^{7}$ $\mathrm{cfu} / \mathrm{ml}$. Setelah itu, suspensi bakteri dicampurkan dengan suspensi silika nano dan serat karbon dalam aquadest. Silika nano yang digunakan dalam pengujian memiliki ukuran $100 \mathrm{~nm}$ dengan konsentrasi 3\%, sedangkan serat karbon yang digunakan memiliki ukuran 80 Mesh $(0,177 \mathrm{~mm})$ dengan konsentrasi $5 \%$.

\section{Pelaksanaan Percobaan}

Pelaksaanan percobaan yang dilakukan pertama kali yaitu merendam benih bawang merah didalam pestisida berbahan aktif mankozeb $80 \%$ sebanyak $1 \mathrm{~g} / 500 \mathrm{ml}$ selama 5 menit, kemudian dikeringanginkan selama 2 hari sebelum tanam. Hal ini dilakukan untuk mencegah bawang merah terserang oleh patogen lain seperti penyakit moler. Kemudian memotong ujung umbi bawang merah kurang lebih $1 \mathrm{~cm}$. Selanjutnya merendam umbi bawang merah ke dalam masing-masing perlakuan uji sebanyak $15 \mathrm{ml}$ selama 10 menit.

Kedua melakukan penanaman bawang merah dengan membenamkan 2 umbi bawang merah per polybag $(25 \times 30 \mathrm{~cm})$ pada media tanah steril dan kompos yang telah dicampur dengan perbandingan 2:1. Selanjutnya suspensi uji sisa perendaman disiramkan ke sekitar lubang tanam umbi bawang merah sebanyak $10 \mathrm{ml}$. Pada kontrol hanya disiram dengan air sebanyak $10 \mathrm{ml}$. Pada daun bawang merah umur 2 minggu setelah tanam (MST), dilakukan inokulasi isolat $A$. porri dengan cara menyemprotkan suspensi spora sebanyak 15 $\mathrm{ml} /$ tanaman dengan kerapatan spora $10^{7} \mathrm{spora} / \mathrm{ml}$. Kemudian dilakukan penyungkupan selama 3 hari.

\section{Pengamatan}

Pengamatan yang dilakukan yaitu masa inkubasi penyakit bercak ungu, dilakukan setiap hari dari awal inokulasi hingga timbul gejala pertama serta intensitas penyakit bercak ungu, diketahui dengan mengamati gejala eksternal pada tanaman. Pengamatan dilakukan setiap tiga hari sekali. Tingkat keparahan penyakit dihitung menggunakan rumus:

$$
x=\frac{\Sigma(n x v)}{N X Z} \times 100 \%
$$

\section{Keterangan:}

$\mathrm{X}=$ intensitas penyakit

$\mathrm{n}=$ jumlah tanaman dengan skor yang sama

$\mathrm{v}=$ jumlah tanaman yang terinfeksi

$\mathrm{N}=$ jumlah tanaman sampel

$\mathrm{Z}=$ nilai tertinggi

Skoring yang digunakan adalah:

$0=$ tidak terjadi gejala

$1=$ daun terinfeksi sebesar $0<\mathrm{X} \leq 12 \%$

2 = daun terinfeksi sebesar $12 \%<\mathrm{X} \leq 25 \%$

3 = daun terinfeksi sebesar $25 \%<\mathrm{X} \leq 50 \%$ 
$4=$ daun terinfeksi sebesar $50 \%<\mathrm{X} \leq 75 \%$

5 = daun terinfeksi sebesar $75 \%<X \leq 100 \%$

Data intensitas kemudian digunakan untuk menghitung Area Under Disease Progress Curve (AUDPC). Rumus AUDPC (Campbell \& Madden, 1990) adalah:

$$
\text { AUDPC }=\sum_{i}^{n-1}\left(\frac{y_{i}+y_{i+1}}{2}\right)\left(t_{i+1}-t_{i}\right)
$$

Keterangan:

$$
\begin{aligned}
\mathrm{Y}_{\mathrm{i}+1} & =\text { data pengamatan ke-i+1 } \\
\mathrm{Y}_{\mathrm{i}} & =\text { data pengamatan ke-i } \\
\mathrm{t}_{\mathrm{i}+1} & =\text { waktu pengamatan ke-i+1 } \\
\mathrm{t}_{\mathrm{i}} & =\text { waktu pengamatan ke-i }
\end{aligned}
$$

Data AUDPC yang diperoleh kemudian dipergunakan sebagai data untuk menghitung penghambatan dari setiap perlakuan. Presentase penghambat dari setiap perlakuan tersebut dihitung dengan menggunakan rumus:

Penghambatan $=1-\frac{\text { AUDPC }_{\text {Perlakuan }}}{\text { AUDPC }_{\text {Kontrol }}} \times 100 \%$

Penghitungan tinggi tanaman dan jumlah daun tanaman bawang merah dilakukan setiap 1 minggu sekali. Variabel ini diamati hingga bawang merah berumur 6 MST. Pengamatan tinggi tanaman dan jumlah daun bertujuan untuk mengetahui respons tanaman bawang merah pada saat diaplikasikan perlakuan.

\section{HASIL DAN PEMBAHASAN}

\section{Masa Inkubasi Penyakit Bercak Ungu}

Berdasarkan hasil pengamatan, gejala awal penyakit bercak ungu pada tanaman bawang merah mulai terlihat pada 3 hingga 7 hari setelah inokulasi (HSI). Gejala yang timbul pada percobaan yaitu diawali dengan adanya bintik-bintik kecil berjumlah banyak dan tidak beraturan, berwarna putih, serta melengkung kedalam. Bercak nekrotik tersebut kemudian melebar, disertai dengan bagian tengah berwarna cokelat dengan tepi berwarna kuning (Gambar 1).
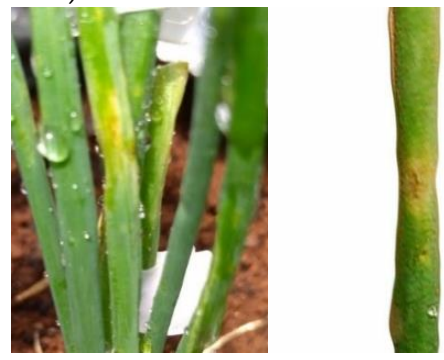

Gambar 1. Gejala penyakit bercak ungu ( $A$. porrı)

Pernyataan tersebut sesuai dengan penelitian Everts (1996) bahwa masa inkubasi dari bercak ungu adalah 3 hari setelah inokulasi, dengan gejala awal yaitu terdapat bintik-bintik berwarna putih dengan jumlah yang banyak, memiliki bentuk lingkaran atau tidak beraturan serta berukuran kurang dari satu milimeter. Pada Tabel 2 dapat dilihat bahwa masa inkubasi bercak ungu pada setiap perlakuan berbeda-beda. Masa inkubasi tersebut memiliki rentang waktu 3 hingga 7 hari.

Tabel 2. Masa inkubasi bercak ungu dan intensitas penyakit

\begin{tabular}{ccc}
\hline Perlakuan & $\begin{array}{c}\text { Masa Inkubasi } \\
(\mathrm{HSI})\end{array}$ & $\begin{array}{c}\text { Intensitas } \\
\text { Penyakit (\%) }\end{array}$ \\
\hline $\mathrm{A}$ & 7 & 4 \\
\hline $\mathrm{B}$ & 3 & 4 \\
\hline $\mathrm{C}$ & 7 & 8 \\
\hline $\mathrm{D}$ & 3 & 8 \\
\hline $\mathrm{E}$ & 3 & 9,33 \\
\hline $\mathrm{F}$ & 3 & 5,33 \\
\hline $\mathrm{G}$ & 3 & 5,33 \\
\hline $\mathrm{H}$ & 3 & 14,67 \\
\hline
\end{tabular}

Perlakuan A dan C, memiliki masa inkubasi 7 hari. Kedua perlakuan tersebut memiliki intensitas terendah dengan persentase $4 \%$ dan $8 \%$. Hal ini diduga oleh peranan bakteri didalamnya, bakteri $B$. subtilis (PGPR) dapat menginduksi ketahanan bawang merah untuk menghalangi patogen agar menginfeksi kedalam jaringan tanaman, dan memberikan sinyal bagi tanaman agar tanaman menjadi tahan. Selain itu, Lysinibacillus sp. (endofit) memiliki peran untuk melindungi tanaman dari bagian dalam jaringan tanaman. Penggunaan silika nano dapat berfungsi untuk meningkatkan ketahanan jaringan tanaman seperti dengan mempertebal dinding epidermis tanaman agar tidak mudah terserang oleh patogen.

Pada perlakuan kontrol masa inkubasi bercak ungu yaitu 3 hari. Perlakuan tersebut memiliki intensitas tertinggi, dengan persentase $14,67 \%$, dibandingkan dengan perlakuan lainnya. Hal ini diduga pada perlakuan kontrol tidak ada bakteri yang bekerja, sehingga tanaman bawang merah tidak memiliki ketahanan. Berdasarkan hasil penelitian Febriyanti (2015), bakteri B. subtilis (PGPR) mampu menunda masa inkubasi Peanut Stripe Virus (PStV). Selain itu, berdasarkan penelitian Hersanti (2016), bakteri Lysinibacillus sp. 
mampu memperpanjang masa inkubasi Phytophthora infestans pada kentang.

\section{Intensitas Penyakit Bercak Ungu}

Pengukuran dilakukan 3 hari sekali sejak gejala pertama, bertujan untuk mengetahui tingkat keparahan penyakit bercak ungu pada tanaman bawang merah dari mulai awal munculnya gejala hingga akhir. Semakin rendah grafik intensitas penyakit, maka perlakuan tersebut mampu untuk menekan perkembangan patogen. Pengamatan intensitas penyakit bercak ungu dari masing-masing perlakuan disajikan pada Gambar 2.

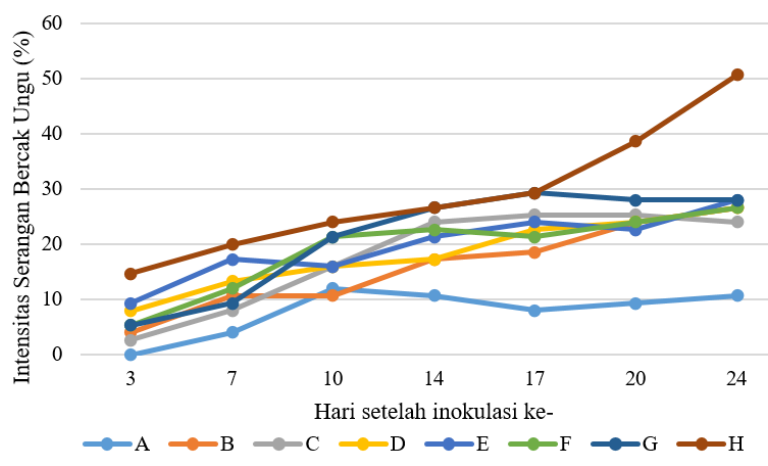

Gambar 2. Intensitas serangan penyakit bercak ungu

Pada Gambar 2 dapat dilihat bahwa gejala penyakit bercak ungu meningkat pada 7 hari setelah inokulasi (HSI) di semua perlakuan. Perlakuan A, merupakan perlakuan yang mampu untuk menekan perkembangan penyakit bercak ungu. Kejadian ini diduga karena, dalam formulasi tersebut terdapat sinergisme kerja antara konsorsium bakteri, silika nano dan serat karbon. Pernyataan ini sesuai dengan Asri (2016), penggunaan konsorsium mikroba cenderung memberikan hasil yang lebih baik dibandingkan penggunaan isolat tunggal, karena kerja enzim dari tiap jenis mikroba dapat saling melengkapi untuk dapat bertahan hidup. Selain itu, berdasarkan penelitian Sundaramoorthy (2012), bahwa dengan perlakuan konsorsium B. subtilis (PGPR) dan $P$. fluorescens mampu menekan pekembangan Alternaria solani sebesar $61,5 \%$ dibandingkan dengan perlakuan tunggal menggunakan B. subtilis (PGPR) sebesar 48,2\% dan $P$. fluorescens sebesar 45,3\%.

Penggunaan silika nano pada formulasi juga memberikan efek positif untuk menekan perkembangan penyakit bercak ungu. Hal ini diduga karena silika mampu meningkatkan ketahanan pada tanaman bawang merah, salah satunya dapat mempertebal jaringan epidermis tanaman.
Berdasarkan penelitian Heine (2007), efek positif dari pemberian silika yaitu mampu menurunkan serangan penyakit Phytium aphanidermatum pada tanaman Mormodica charantia (paria). Perlakuan kontrol merupakan perlakuan yang memiliki intensitas penyakit yang signifikan meningkat dari hari ke hari dibandingkan dengan perlakuan lainnya.

Berdasarkan data Stasiun Cuaca Fakultas Pertanian, Universitas Padjadjaran, pada bulan Mei hingga Juni 2018 di Ciparanje, Universitas Padjadjaran rata-rata suhu $23,4^{\circ} \mathrm{C} \quad-29,6^{\circ} \mathrm{C}$, sedangkan rata-rata kelembaban yaitu sebesar $88 \%$. Faktor iklim tersebut mampu mendukung perkembangan $A$. porri untuk menginfeksi.

Penekanan setiap perlakuan terhadap penyakit bercak ungu pada tanaman bawang merah dapat diketahui dengan menghitung Area under disease progress curve (AUDPC). Nilai AUDPC didapatkan dari intensitas penyakit setiap interval waktu pengamatan. Semakin kecil nilai AUDPC, maka semakin baik penekanan terhadap penyakit. Nilai AUDPC dan persentase penghambatan bercak ungu pada berbagai perlakuan disajikan pada Tabel 3.

Tabel 3. Nilai AUDPC dan penghambatan (\%) bercak ungu pada berbagai perlakuan

\begin{tabular}{ccc}
\hline Perlakuan & AUDPC & Penghambatan (\%) \\
\hline A & $148 \mathrm{a}$ & 71,2 \\
\hline B & $290 \mathrm{~b}$ & 43,6 \\
\hline C & $336 \mathrm{~b}$ & 34,6 \\
\hline$D$ & $332 \mathrm{~b}$ & 35,4 \\
\hline E & $360 \mathrm{~b}$ & 30,0 \\
\hline F & $352 \mathrm{~b}$ & 31,5 \\
\hline$G$ & $394 \mathrm{bc}$ & 23,3 \\
\hline$H$ & $514 \mathrm{~cd}$ & 0
\end{tabular}

Keterangan: Huruf yang sama pada satu kolom dalam tabel menunjukkan data tidak berbeda nyata berdasarkan Uji Duncan HSD 5\%

Berdasarkan hasil analisis terhadap nilai AUDPC (Tabel 3) dapat dilihat bahwa perlakuan yang dapat menekan perkembangan bercak ungu sebesar lebih dari 50\% yaitu perlakuan A. Persentase penghambatan yang didapatkan yaitu sebesar $71,2 \%$. Persentase penghambatan tersebut tergolong lebih tinggi dibandingkan dengan perlakuan yang lainnya. Kejadian ini dapat diduga karena penggunaan mikroba antagonis secara konsorsium memiliki efek positif, salah satunya adanya sinergisme peran dari masing-masing bakteri B. subtilis (PGPR) dan Lysinibacillus sp. (endofit) yang dapat menginduksi 
ketahanan bawang merah terhadap patogen bercak ungu. Selain itu, silika nano yang diaplikasikan mampu diserap secara optimal oleh tanaman bawang merah, menyebabkan tanaman menjadi tahan. Penggunaan serat karbon sebagai bahan pembawa pada formulasi mikroba antagonis diduga tepat, karena dapat memertahankan populasi bakteri dan menjaga kemampuan bakteri dalam menginduksi ketahanan tanaman.

Pernyataan tersebut sesuai dengan penelitian Hersanti (2016), bahwa perlakuan menggunakan Lysinibacillus sp. dan B. subtilis (PGPR) mampu menghambat serangan patogen $P$. infestans dengan baik yaitu penghambatannya sebesar 84,15\% dan 40,59\%. Penelitian Zhang (2010), aplikasi Lysinibacillus boronitolerans terbukti dapat menghambat patogen Phytophthora capsici pada tanaman labu dengan mekanisme induksi resistensi sistemik. Berdasarkan penelitian Riana (2011), penggunaan bakteri konsorsium Pseudomonas fluorescens dan Bacillus subtilis mampu menekan perkembangan penyakit blast pada padi sebesar 69,92\% hingga 79,05\%.

Perlakuan dengan menggunakan silika nano mampu menguatkan jaringan dan meningkatkan ketahanan tanaman. Hal ini sesuai dengan pernyataan Husnain (2011) bahwa unsur Si pada tanaman secara umum dapat memperbaiki fungsi fisiologi, menguatkan jaringan dan meningkatkan ketahanan tanaman terhadap serangan hama dan patogen sehingga meningkatkan pertumbuhan dan produksi tanaman. Pemberian asupan Si yang cukup dilaporkan mampu menekan penyakit karat yang disebabkan oleh jamur Puccinia kuehnii, bintik hitam oleh Dimeriella sacchari, dan penyakit noda cincin yang disebabkan oleh jamur Helminthosporium sacchari pada tanaman tebu (Matichenkov \& Calvert, 2002).

\section{Tinggi Tanaman dan Jumlah Daun}

Tinggi tanaman bawang merah diukur dari pangkal bawah tanaman hingga ujung daun tertinggi dari bawang merah. Pengamatan dilakukan pada umur bawang 1 minggu setelah tanam (MST) hingga 6 MST, sesuai fase tumbuh bawang merah. Data pengamatan tinggi tanaman disajikan pada Gambar 3.



Gambar 3. Tinggi tanaman bawang merah pada berbagai perlakuan

Berdasarkan hasil pengukuran tinggi tanaman pada berbagai perlakuan (Gambar 3) menunjukkan bahwa tinggi tanaman bawang merah mengalami peningkatan dimulai pada umur 1 MST hingga 3 MST. Selanjutnya, tinggi tanaman bawang merah tetap. Pada umur tanaman 1 MST, rata-rata tanaman memiliki tinggi $\pm 17 \mathrm{~cm}$. Kemudian, pada umur tanaman 2 MST, tanaman bawang merah pada setiap perlakuan memiliki rata-rata tinggi $\pm 31 \mathrm{~cm}$. Akan tetapi, tinggi tanaman bawang merah tidak terpengaruh oleh berbagai perlakuan. Tinggi tanaman pada berbagai perlakuan memiliki rata-rata yang sama. Kejadian ini diduga karena tanaman bawang merah kekurangan cahaya pada saat penanaman di rumah kaca dan jarak tanam antar tanaman yang terlalu dekat.

Akibat dari tanaman bawang merah kekurangan cahaya dan jarak tanam yang terlalu dekat (Gambar 4) yaitu tinggi tanaman yang meningkat secara pesat, daun bawang tidak tegak, batang daun memiliki ukuran yang kecil, dan warna daun yang hijau pucat. Bawang merah membutuhkan cahaya matahari secara langsung, sehingga proses fotosintesis pada tanaman bawang merah optimal. Selain itu, jarak tanam yang terlalu dekat menghasilkan tanaman bawang merah yang lebih tinggi, diduga karena adanya persaingan untuk mendapatkan cahaya matahari. Hal ini didukung oleh penelitian Nugrahini (2013), bahwa jarak tanam pada bawang merah yang terlalu rapat $10 \mathrm{~cm}$ x $10 \mathrm{~cm}$, memiliki rata-rata tinggi tanaman 43,79 $\mathrm{cm}$, hasil tersebut sangat tinggi dibandingkan dengan jarak tanam yang lebih lebar. 

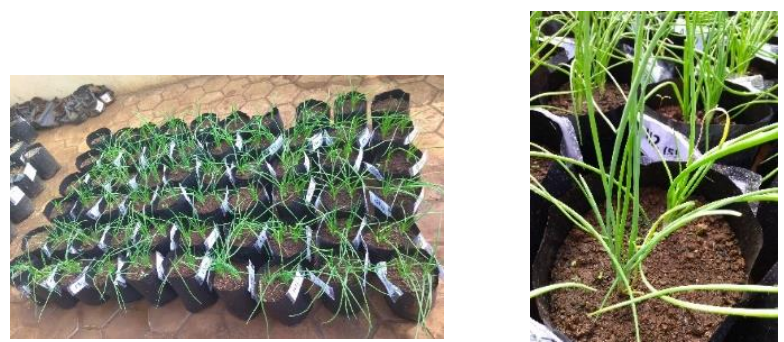

Gambar 4. Tanaman bawang merah kekurangan cahaya dan jarak tanam yang terlalu dekat

Jumlah daun dihitung pada saat tanaman bawang merah berumur 1 MST hingga berumur 6 MST dengan cara menghitung jumlah daun yang segar dan masih berwarna hijau. Data pengamatan jumlah daun dapat dilihat pada Gambar 5.

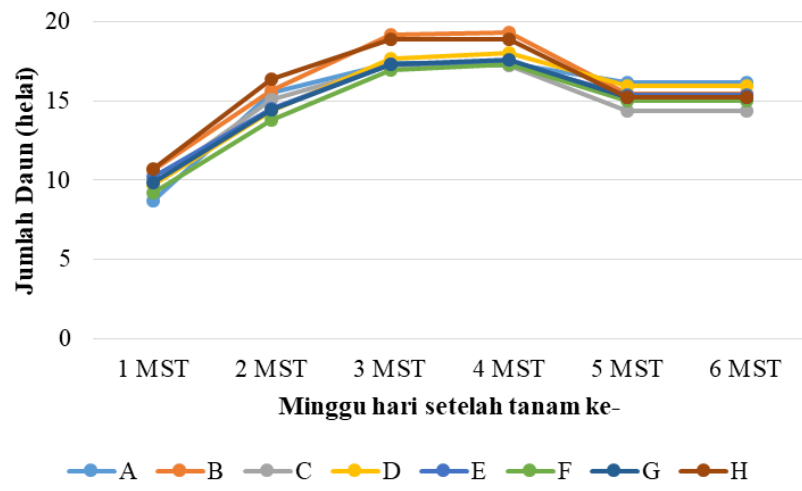

Gambar 5. Jumlah daun tanaman bawang merah pada berbagai perlakuan

Hasil rata-rata jumlah daun pada Gambar 5 menunjukkan bahwa pada setiap perlakuan terjadi fluktuatif. Pada umur tanaman bawang merah 1 MST hingga 3 MST tanaman bawang merah mengalami pertumbuhan jumlah daun. Pada umur 1 MST, bawang merah memiliki rata-rata jumlah daun sebanyak \pm 9-10 helai daun, sedangkan pada umur 3 MST, bawang merah memiliki rata-rata jumlah daun sebanyak \pm 17-18 helai daun. Setelah itu, pada umur tanaman bawang merah 4 MST, rata-rata jumlah daun stagnan. Namun, pada umur tanaman 5 MST hingga 6 MST rata-rata jumlah daun pada bawang merah mengalami penurunan. Rata-rata pada umur 5 MST hingga 6 MST yaitu $\pm 14-16$ helai. Akan tetapi, jumlah daun bawang merah tidak dipengaruhi perlakuan. Jumlah daun pada berbagai perlakuan memiliki rata-rata yang sama. Hal ini diduga oleh beberapa faktor, seperti efek dari kekurangan cahaya, sehingga menghambat proses fotosintesis pada tanaman bawang merah. Efek dari kekurangan terhadap jumlah daun yaitu bentuk daun yang lebih kecil dan jumlah daun yang lebih sedikit dikarenakan hasil fotosintesis banyak digunakan untuk pertumbuhan tinggi tanaman. Selain itu, daun menjadi rapuh dan mudah patah, karena daun mengikuti arah cahaya matahari sehingga daun menjadi rebah.

Berdasarkan penelitian Nugrahini (2013), bahwa pada jarak tanam bawang merah yang terlalu rapat, $10 \mathrm{~cm} \times 10 \mathrm{~cm}$, rata-rata jumlah daun 11,41 helai. Sepanjang masa pertumbuhan vegetatif seperti akar, batang dan daun merupakan daerah-daerah pemanfaatan yang kompetitif dalam hal pemanfaatan hasil asimilasi. Proporsi hasil asimilasi pada bagian-bagian vegetatif tersebut dapat memengaruhi pertumbuhan dan hasil tanaman.

\section{SIMPULAN}

Berdasarkan hasil penelitian dapat disimpulkan bahwa campuran Bacillus subtilis dan Lysinibacillus sp. dalam silika nano serta serat karbon mampu meningkatkan ketahanan tanaman bawang merah dengan penghambatan intensitas penyakit bercak ungu sebesar $71,2 \%$.

\section{DAFTAR PUSTAKA}

Aiman, U, dan TB Sriwijaya. 2017. Pemberian macam konsorsium bakteri hasil isolasi tumbuhan pantai pada kangkung (Ipomoea reptans Poirs.). Jurnal Agrosains. 5(1): 1-6.

Asri, AC, dan E Zulaika. 2016. Sinergisme antar isolat Azotobacter yang dikonsorsiumkan. Jurnal Sains dan Seni ITS. 5(2): 2337-3520.

Berendsen, RL, G Vismans, K Yu, Y Song, RD Jonge, WP, Burgman, M Burmolle, J Herschend, PAHM Bakker, and CMJ Pieterse. 2018. Disease-induced assemblage of a plantbeneficial bacterial consortium. Journal The ISME 12: 1496-1507.

Everts, KL. 1996. Factors influencing infection of onion leaves by Alternaria porri and subsequent lesion expansion. Plant Dis. 80: 276-280.

Febriyanti, LE, M Martosudiro, and T Hadiastono. Pengaruh Plant Growth Promoting Rhizobacteria (PGPR) terhadap infeksi Peanut Stripe Virus (PStV), pertumbuhan dan produksi tanaman kacang tanah (Arachis hypogaea L.) varietas Gajah. Jurnal HPT. 3(1): 84-94.

Hadisutrisno, B, Sudarmadi, S Siti, dan P Achmadi. 1996. Peranan faktor cuaca terhadap infeksi 
dan perkembangan penyakit bercak ungu pada bawang merah. J. Plant Prot. 1(1): 5664.

Hanudin, W Nuryani, ES Yusuf, dan B Marwoto. 2011. Biopestisida organik berbahan aktif Bacillus subtilis dan Pseudomonas fluorescens untuk mengendalikan penyakit layu fusarium pada anyelir. Jurnal Hortikultura. 21(2): 152-163.

Heine, G, G Tikum, and W Horst. 2007. The effect of silicon on the infection by spread of Phytium aphanidermatum in single roots of tomato and bitter gourd. J. of Experimantal Botany. 58: 569-577.

Hersanti, L Djaya, F Muhamad, dan ET Heni. 2016. Pengujian bakteri endofit dan Plant Growth Promoting Rhizobacteria (PGPR) untuk mengendalikan penyakit layu bakteri (Rasltonia solanacearum) dan busuk daun (Phytophthora infestans) pada tanaman kentang. Prosiding Seminar Nasional Pengendalian Penyakit Pada Tanaman Ramah Lingkungan II Perhimpunan Fitopatologi Indonesia Komda Joglosemar. Hlm. 269-279.

Hersanti, A Susanto, N Istifadah, dan WR Pawstri. 2017. Keefektifan bakteri Lysinibacillus sp. dalam formulasi silika nano dan serat karbon untuk menekan perkembangan Ralstonia solanacearum secara in vitro. Seminar Nasional Kongres XXIV Perhimpunan Fitopatologi Indonesia. Kendari, 3-5 Oktober 2017.

Husnain, S Rochayati, dan I Adamy. 2011. Sumber hara silika untuk pertanian. Warta Penelitian dan Pengembangan Pertanian. 33(3): 12-13.

Leiwakabessy, C, MS Sinaga, KH Mutaqien, Trikoesoemaningtyas, and Giyanto. 2018. The endophytic bacteria, salicylic acid, and their combination as inducers of rice resistance against Xanthomonas oryzae pv. oryzae. Agrivita Journal of Agricultural Science. 40(1): 25-35.

Matichenkov, VV, and DV Calvert. 2002. Silicon as a beneficial element for sugarcane. Journal American Society of Sugarcane Technologiest. 22: 21-30.

Nugrahini, T. 2013 Respon tanaman bawang merah (Allium ascolonicum L.) varietas Tuk Tuk terhadap pengaturan jarak tanam dan konsentrasi Pupuk Organik Cair Nasa. Ziraa'ah. 36(1): 60-65.
Pieterse, CMJ, C Zamioudis, RL Berendsen, DM Weller, SCMV Wees, and PAHM Bakker. 2014. Induced systemic resistance by benefical microbes. Annual Review of Phytopathology. 52: 347-375.

Ruhyaman, RR, Hersanti, S Hartati, M Setiawati, IM Joni. 2017. Efficacy of Bacillus subtilis in Nano silica and carbon fiber formulation for control of Ralstonia solanacearum under in vitro conditions. $5^{\text {th }}$ Asian Plant GrowthPromoting Rhizobacteria International Conference for Sustainable Agriculture. P. 150.

Riana, E. 2011. Seleksi dan Formulasi Konsorsium Bakteri untuk Mengendalikan Penyakit Blas (Pyricularia oryzae) pada Tanaman Padi. [Skripsi]. Institut Pertanian Bogor. Bogor.

Sari, MP, H Bambang, dan Suryanti. 2016. Penekanan perkembangan penyakit bercak ungu pada bawang merah oleh cendawan mikoriza arbuskula. Jurnal Fitopatologi Indonesia. 12(5): 159-167.

Sundaramoorthy, S, and P Balabaskar. 2012. Consortial Effect of Endophytic and Plant Growth Promoting Rhizobacteria for the Management of Early Blight of Tomato Incited by Alternaria solani. J Plant Pathol Microb. 3:145.

Suhardi, T, Koestoni, dan AT Soetiarso. 1994. Pengujian teknologi pengendalian hama terpadu pada tanaman bawang merah berdasarkan ambang kendali dan modifikasi tipe nozzle alat semprot. Bul penel Hor. 26(4): 10-17.

Tarigan, R, B Susilawati, dan L Agung. 2015. Penggunaan asam asetil salisilat terhadap pengendalian penyakit alternaria porri (trotol) pada tanaman bawang merah. Prosiding Seminar Nasional Sains dan Teknologi Pertanian. Hlm. 298-310.

Yuliani, K, Ngadiwiyana, S Eko, AA Diah, W Yoyon, dan W Dita. 2015. Pengaruh kombinasi silika dan kitosan berbasis nanoteknologi sebagai bahan dasar pembuatan pupuk nano slow release terhadap penyerapan unsur hara oleh tanaman dalam meningkatkan hasil pertanian di Indonesia. Artikel Ilmiah Teknologi Kimia dan Industri. Tersedia online pada http://ejournals1.undip.ac.id/index.php.

Zhang, J, F Shao, Y Li, H Cui, L Chen, H Li, Y Zou, C Long, L Lan, J Chai, S Chen, X Tang, and JM Zhou. 2007. A Pseudomonas syringae 
effector inactives MAPKs to suppress PAMP-induced immunity in plants. Cell Host \& Microbe Article. 1: 175-185.

Zhang, S, TWhite, L, MC Martinez, JA McInroy, JW

Kloepper, and W Klassen. 2010. Evaluation of plant growth-promoting rhizobacteria for control of Phytophthora blight on squash under greenhouse conditions. Biological Control. 53: 129-135. 